\title{
Adaptive acid tolerance response (ATR) in Aeromonas hydrophila
}

\author{
Kevin L. Karem, ${ }^{1}$ John W. Foster ${ }^{1}$ and Asim K. Bej ${ }^{2}$ \\ Author for correspondence: Asim K. Bej. Tel: +1 2059349857 or 5393. Fax: +1 2059756097. \\ e-mail : BioF003(aUABDPO.DPO.UAB.EDU
}

\begin{abstract}
1 Department of Microbiology and Immunology, University of South Alabama, Mobile, AL 36688, USA

2 Department of Biology, University of Alabama at Birmingham, Birmingham, AL 35294-1170, USA
\end{abstract}

\begin{abstract}
Aeromonas hydrophila, a gastrointestinal pathogen of humans, was shown to exhibit a significant adaptive acid tolerance response (ATR) capable of protecting cells from severe acid at a pH of 3.5. The ATR was induced by exposure to a relatively mild pH level of 5.0 for $20 \mathrm{~min}$. Adaptation required protein synthesis since treatment with chloramphenicol during adaptation to pH 5.0 prevented the development of acid tolerance. The adaptation to acid environment was found to be a non-transient phenomenon. Also, iron was not required for acid adaptation in A. hydrophila. Two-dimensional protein analyses revealed an increased production of 28 proteins and decreased synthesis of 10 following pH shifts from 7.2 to 5.0. The mild pH treatment must act as a signal to $A$. hydrophila to adapt and survive in acid environments by producing 'protective' proteins. The adaptation and survival of this pathogen in low pH may provide valuable information about its ability to withstand acid environments in nature and in the human gastrointestinal tract.
\end{abstract}

Keywords: Aeromonas bydrophila, acid adaptation, acid tolerance response (ATR), low pH adaptation, gastrointestinal pathogen

\section{INTRODUCTION}

Bacterial survival in stressful environments is an intriguing biological problem with applications toward understanding pathogenic and environmentally important micro-organisms. A number of stress conditions such as starvation (Jenkins et al., 1988, 1990; Siegele \& Kolter, 1992), heat-shock (Allen et al., 1992; Foster, 1992; Henry et al., 1992), cold-shock (Goldstein et al., 1990; Jones $e t$ al., 1992; Willimsky et al., 1992), and pH (Foster, 1992; Slonczewski, 1992; White et al., 1992) have been documented for a number of microbial pathogens. In each case global physiological changes were shown to occur within the cell when they were exposed to the stress condition (Murray \& Young, 1992; Pannekoek et al., 1992; Nystrom \& Neidhardt, 1992). Many of the stress conditions formed part of the host defence system used to prevent or limit bacterial infections (Gluskin et al., 1992). An important stress condition that must be faced by many pathogenic micro-organisms is low $\mathrm{pH}$. Upon ingestion, food- and water-borne microbial pathogens are exposed to an acid $\mathrm{pH}$ environment in the stomach and in the small intestine (Booth, 1985; Goodson \& Rowbury, 1989a, b, c, 1990). Also, some of these microbial pathogens can be

Abbreviations: ATR, acid tolerance response; DTPA, dipyridyl. exposed to acid conditions in the urinary tract and in the phagolysosome (Goodson \& Rowbury, 1989b; Raja et al., 1991). Adaptation and survival in a low $\mathrm{pH}$ environment may be an important prerequisite toward the production of disease by many gastrointestinal pathogens. The response to low $\mathrm{pH}$ environments has been studied in Salmonella typhimurium (Aliabadi et al., 1988; Foster, 1991, 1992; Foster \& Hall, 1990), Escherichia coli (Slonczewski, 1992; Raja et al., 1991; Watson et al., 1992), Streptococcus mutans (Hamilton \& Buckley, 1991) and Helicobacter pylori (Mooney et al., 1990).

Among a wide variety of potential water- and food-borne gastrointestinal microbial pathogens, Aeromonas spp. have recently drawn significant attention due to their role in causing acute diarrhoeal disease (Schubert, 1991). Various species of Aeromonas are widely distributed in polluted and unpolluted aquatic environments (Hazen et al., 1978a). Among the Aeromonas spp. isolated from various aquatic environments, $A$. bydrophila is found to be predominant (approximately 70\%) (Schubert, 1991). Although $A$. bydropbila is recognized as a primary pathogen of fish, reptiles, and amphibia (Hazen et al., 1978b; Hird et al., 1981) and is considered an opportunistic pathogen of immunocompromised humans (Gluskin et al., 1992; Von Gravenitz \& Mensch, 1968), numerous recent reports suggest that this pathogen can 
cause serious infection in patients without known immunological abnormalities (Gluskin et al., 1992; Schubert, 1991 ; Monfort \& Baleux, 1991). During the last decade, $A$. hydropbila has been traced as a causative agent for acute diarrhoeal disease in humans following ingestion of contaminated water (Burke et al., 1984; Cumberbatch $e t$ al., 1979; Figura et al., 1986; Kirov et al., 1986; Pitarangsi et al., 1982). As a result, $A$. bydropbila is now considered a significant enteric pathogen (Janda \& Duffy, 1988).

Because $A$. bydrophila is a waterborne pathogen (Schubert, 1991) it must cope with environmental as well as hostassociated acid stress (Schubert, 1991; Figura et al., 1986; Kirov et al., 1986). Consequently its ability to survive these acid encounters must contribute to its persistence in nature and its pathogenesis in man. This report initiates a study designed to dissect the cellular and physiological responses of $A$. bydrophila to severe external acid stress conditions.

\section{METHODS}

Bacterial strains and media. Two strains of $A$. bydrophila were used in this study. A. bydropbila ATCC 7965 was obtained from the American Type Culture Collection. A second strain, $A$. bydrophila SM 20, isolated from the Ohio river at Louisville, Kentucky, was a gift from S. McCarty of the Louisville Water Company. Both strains were grown and maintained on nutrient agar (Difco) media at $25^{\circ} \mathrm{C}$ or in liquid Luria-Bertani (LB) broth (Miller, 1972) with gentle shaking (80-100 r.p.m.). In addition, $\mathrm{M} 9$ glucose salt minimal medium was used (per litre): $6 \mathrm{~g} \mathrm{Na}_{2} \mathrm{HPO}_{4}, 3 \mathrm{~g} \mathrm{KH}_{2} \mathrm{PO}_{4}, 0.5 \mathrm{~g} \mathrm{NaCl}, 1 \mathrm{~g} \mathrm{NH}{ }_{4} \mathrm{Cl}, \mathrm{pH} 7 \cdot 2$; after autoclaving filter $(0 \cdot 2 \mu \mathrm{m}$ pore size Acrodisc, Gelman)sterilized solutions of $10 \mathrm{ml} 0.01 \mathrm{M} \mathrm{CaCl}, 1 \mathrm{ml} 1 \mathrm{M}$ $\mathrm{MgSO}_{4} \cdot 7 \mathrm{H}_{2} \mathrm{O}$, and $10 \mathrm{ml} 20 \%(\mathrm{w} / \mathrm{v})$ glucose were added (Miller, 1972).

Acid adaptation and viable plate counts. A $1 \mathrm{ml}$ culture of $A$. bydrophila was inoculated into three sterile flasks each containing $100 \mathrm{ml} \mathrm{LB}$ broth or glucose salts minimal medium and grown on a rotary shaker at $25^{\circ} \mathrm{C}$ until an $\mathrm{OD}_{450}$ of 0.2 was reached $\left(100 \%\right.$ viability was estimated to be $2 \times 10^{6}$ cells $\mathrm{ml}^{-1}$ by viable plate counts). The $\mathrm{pH}$ of one of the cultures (adapted) was adjusted to 5.0 by addition of a $50 \%(\mathrm{v} / \mathrm{v})$ solution of $\mathrm{HCl}$ (Fisher Scientific), and the incubation of the cells was continued for $20 \mathrm{~min}$ at $25^{\circ} \mathrm{C}$ with shaking. The cells in this culture were then challenged to $\mathrm{pH} 3.5$ by adding additional $\mathrm{HCl}$, and incubated for another $2.5 \mathrm{~h}$. At the same time, another culture was grown at $\mathrm{pH} 7 \cdot 2$ to $\mathrm{OD}_{450} 0 \cdot 2\left(2 \times 10^{6}\right.$ cells $\left.\mathrm{ml}^{-1}\right)$ and then challenged to $\mathrm{pH} 3.5$ without an intermediate incubation at $\mathrm{pH} 5 \cdot 0$. As a control, a third culture was maintained at $\mathrm{pH} 7 \cdot 2$ without changing the $\mathrm{pH}$ during the entire period of the experiment.

For viable plate counts, aliquots from each culture were serially diluted in phosphate buffer ( $\mathrm{pH} 7 \cdot 2$ ) (Miller, 1972), and plated onto LB agar plates using the spread plate method. The plates were incubated at $25^{\circ} \mathrm{C}$ for $36-48 \mathrm{~h}$.

Transient acid adaptation. A $1 \mathrm{ml}$ overnight culture of $A$. bydrophila was inoculated into seven sterile flasks each containing $100 \mathrm{ml} \mathrm{LB}$ broth or glucose salts minimal medium and grown on a rotary shaker at $25^{\circ} \mathrm{C}$ to an $\mathrm{OD}_{450}$ of $0.2(100 \%$ viability was estimated at $1.9 \times 10^{6}$ cells $\mathrm{ml}^{-1}$ by viable plate counts). The $\mathrm{pH}$ of five of the seven cultures was adjusted to 5.0 by addition of a $50 \%$ solution of $\mathrm{HCl}$. The $\mathrm{pH}$ of four of these five cultures was shifted to $\mathrm{pH} 3.5$ following adaptation to $\mathrm{pH} 5.0$ for
$15 \mathrm{~min}, 30 \mathrm{~min}, 60 \mathrm{~min}$, or $90 \mathrm{~min}$, respectively and continued to grow for an additional $4 \mathrm{~h}$. Concurrently, two cultures, at $\mathrm{pH} 7 \cdot 2$ and $5 \cdot 0$, were maintained throughout this experimentation as controls.

For viable plate counts, aliquots from each culture before and after the $\mathrm{pH}$ shifts were serially diluted in phosphate buffer ( $\mathrm{pH} 7 \cdot 2$ ) (Miller, 1972), and plated on to LB agar plates using the spread plate method. The plates were incubated at $25^{\circ} \mathrm{C}$ for 36- $-48 \mathrm{~h}$.

Role of iron in acid adaptation. A $1 \mathrm{ml}$ overnight culture of $A$. bydropbila was inoculated into three sterile flasks, each containing $100 \mathrm{ml} \mathrm{LB}$ broth or glucose salts minimal medium and grown on a rotary shaker at $25^{\circ} \mathrm{C}$, to an $\mathrm{OD}_{450}$ of $0.3(100 \%$ viability was estimated at $1 \cdot 2 \times 10^{7}$ cells $\mathrm{ml}^{-1}$ by viable plate counts). One of the three cultures was treated with $100 \mu \mathrm{M}$ dipyridyl (DTPA) (Sigma) as an iron chelator for $15 \mathrm{~min}$ and the $\mathrm{pH}$ was shifted to 5.0. Simultaneously, a second culture was treated with $100 \mu \mathrm{M}$ DTPA and $100 \mu \mathrm{M} \mathrm{Fe}(\mathrm{OH})_{3}$ for $15 \mathrm{~min}$, and the $\mathrm{pH}$ was changed to $5 \cdot 0$. A third culture was simply treated with the adaptation $\mathrm{pH}$ of 5.0 . All cultures were incubated at $\mathrm{pH} 5 \cdot 0$ for $20 \mathrm{~min}$ and then challenged to $\mathrm{pH} 3 \cdot 5$.

For viable plate counts, aliquots from each culture before and after the DTPA, DTPA $+\mathrm{Fe}(\mathrm{OH})_{3}$ treatments and the $\mathrm{pH}$ shifts, were serially diluted in phosphate buffer $(\mathrm{pH} \mathrm{7 \cdot 2)}$ (Miller, 1972), and plated on to LB agar plates using the spread plate method. The plates were incubated at $25^{\circ} \mathrm{C}$ for $36-48 \mathrm{~h}$.

O'Farrell two-dimensional analysis of ATR proteins. Twodimensional protein profiles were determined at different $\mathrm{pH}$ values, following growth in minimal glucose salts medium $(\mathrm{pH} 7 \cdot 2)$ to exponential phase $\left(\mathrm{OD}_{450}\right.$ approximately $\left.0 \cdot 2\right)$. One culture was shifted to a $\mathrm{pH}$ of 5.0 for $20 \mathrm{~min}$, and then labelled with $40 \mu \mathrm{Ci}^{35} \mathrm{~S}$-Trans label (ICN Biomedicals) $\mathrm{ml}^{-1}$ for $15 \mathrm{~min}$. A second culture was maintained at $\mathrm{pH} 7 \cdot 2$ and labelled for an equivalent period of time. Cells were then harvested by centrifugation in a refrigerated centrifuge (Beckman) at 8000 r.p.m. for $15 \mathrm{~min}$, and the cell pellets were resuspended in $13 \mu \mathrm{l}$ of SDS-lysing solution consisting of $50 \mu \mathrm{l} 0.5 \mathrm{M}$ Tris $/ \mathrm{HCl}$ (pH 6.8), $80 \mu \mathrm{l} 15 \%$ (w/v) SDS, $20 \mu \mathrm{l}$ glycerol, $40 \mu \mathrm{l} \beta$ mercaptoethanol and $272 \mu \mathrm{l}$ distilled water (Foster, 1991). The cells were lysed at $95^{\circ} \mathrm{C}$ for $10 \mathrm{~min}$, cooled to room temperature, and $10 \mu \mathrm{l} 100 \% \mathrm{NP} 40$ (Sigma) was added. A $150 \mu \mathrm{l}$ aliquot of SDS-lysis buffer $[5.7 \mathrm{~g}$ urea, $2.0 \mathrm{ml}$ NP40, $0.5 \mathrm{ml} \quad \beta$ mercaptoethanol, $0 \cdot 4 \mathrm{ml}$ pH 5-7 ampholines (BioRad) and $2.4 \mathrm{ml}$ distilled water (Foster, 1991)] was added. The protocol for O'Farrell two-dimensional gel electrophoresis for total cellular proteins was performed as described elsewhere (Dunn et al., 1989; Spector et al., 1986). The first dimension electrophoresis was performed by isoelectric focusing in tube gels containing $1.6 \%(\mathrm{pH} \mathrm{5-7)}$ and $0.4 \%(\mathrm{pH} \mathrm{3-10)}(\mathrm{v} / \mathrm{v})$ Bio-Lyte ampholite (BioRad) and $0.8 \%(\mathrm{pH} \mathrm{5-7)}$ and $0.2 \%(\mathrm{pH} \mathrm{3-10)}$ Bio-Lyte ampholyte as sample overlay buffer. The first dimension tube gels were run at a constant voltage of $200 \mathrm{~V}$ for $2 \mathrm{~h}$, followed by $500 \mathrm{~V}$ for $2 \mathrm{~h}$ and then $800 \mathrm{~V}$ for $16 \mathrm{~h}$ (overnight). The second dimension separation of the proteins was performed in $11.5 \%$ vertical SDS-polyacrylamide slab gels at $160 \mathrm{~V}$ for $10 \mathrm{~h}$ at $12{ }^{\circ} \mathrm{C}$. The gels were dried on Whatman $3 \mathrm{MM}$ filter paper and autoradiography was performed for $72 \mathrm{~h}$ at room temperature.

\section{RESULTS AND DISCUSSION}

\section{Acid adaptation}

Fig. 1 shows that $A$. bydropbila undergoes rapid exponential death when subjected to $\mathrm{pH} 3 \cdot 5$. However, cultures adapted at $\mathrm{pH} 5.0$ for $20 \mathrm{~min}$ with subsequent 


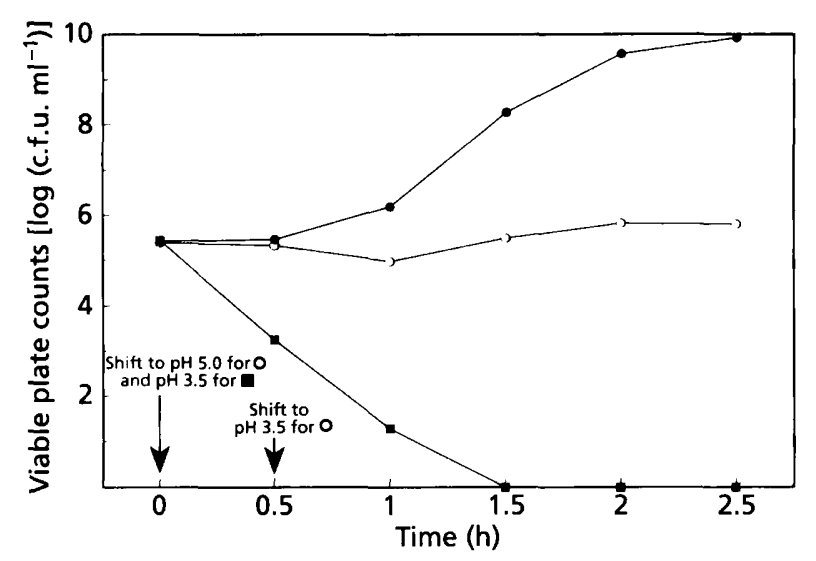

Fig. 1. Viable plate counts of acid induction in Aeromonas hydrophila ATCC 7965. A. A. hydrophila culture maintained at $\mathrm{pH} 7.2 ; \mathrm{O}$, culture adapted to a mild $\mathrm{pH}$ of 5.0 prior to challenge at $\mathrm{pH} 3.5 ; \square$, culture to which the $\mathrm{pH}$ was shifted from 7.2 to 3.5 without any intermediate $\mathrm{pH}$ treatment. The arrows indicate the times when the $\mathrm{pH}$ of each of the cultures was shifted.

challenge to $\mathrm{pH} 3.5$ showed $>5$ log higher survival within $1.5 \mathrm{~h}$ post-acid challenge than cultures without prior adaptation at $\mathrm{pH} 5 \cdot 0$. The unadapted control culture at $\mathrm{pH} 7.2$ continued to grow as expected. Acid adaptation was comparable in both complex and minimal media (data not shown). Thus, survival of $A$. bydrophila at $\mathrm{pH} 3.5$ requires adaptation to an intermediate $\mathrm{pH}$ of $5 \cdot 0$.

\section{ATR development requires protein synthesis}

Acid tolerance could involve the physiological activation of a pre-existing protective system or the induction of specific ATR protective proteins. In order to determine whether synthesis of new proteins is required for acid adaptation, cultures were treated with chloramphenicol $\left(1 \mu \mathrm{g} \mathrm{ml}^{-1}\right)$ immediately before and during adaptation to pH 5.0. Chloramphenicol treatment eliminated the ATR as shown in Fig. 2. This result suggests that proteins synthesized during adaptation at $\mathrm{pH} 5.0$ are involved in the survival during subsequent exposure to $\mathrm{pH} 3 \cdot 5$.

\section{Transient acid adaptation}

The cultures that were adapted at $\mathrm{pH} 5 \cdot 0$ for $15,30,60$ and 90 min and subsequently challenged to $\mathrm{pH} 3.5$ showed survival and growth suggesting the acid adaptation in $A$. bydropbila is not a transient type. The growth of the cells in these cultures was comparable with the growth when the $\mathrm{pH}$ was shifted to 5.0 and then maintained at this $\mathrm{pH}$ (Fig. 3). However, longer exposure to $\mathrm{pH} 5 \cdot 0$ followed by challenge to $\mathrm{pH} 3.5$ increased the viability of the cells (Fig. 3). Also, decreased survival was evident in the culture that was adapted to $\mathrm{pH} 5.0$ for $15 \mathrm{~min}$ followed by challenge to $\mathrm{pH} 3.5$ as compared to the cultures that were adapted for 30, 60, or $90 \mathrm{~min}$ (Fig. 3). In unadapted culture $(\mathrm{pH} 7 \cdot 2 \rightarrow 3 \cdot 5)$, the viability of the cells declined within the first $1.5 \mathrm{~h}$. The culture maintained at 7.2

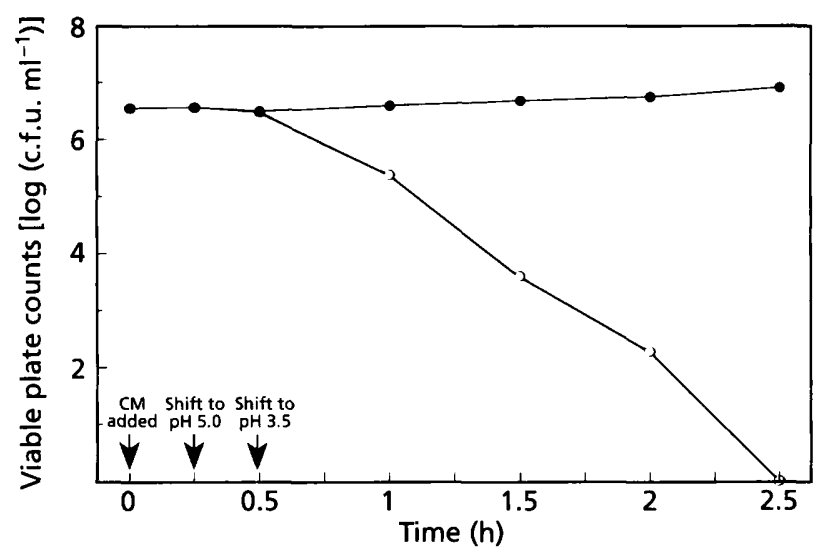

Fig. 2. Viable plate counts of acid induction in chloramphenicol-treated cultures of $\boldsymbol{A}$. hydrophila. 0 , Culture which was not treated with chloramphenicol (CM) before acid $\mathrm{pH}$ shift from 7.2 to 5.0 followed by treatment with a much lower $\mathrm{pH}$ of $3.5 ; 0$, culture which was treated with chloramphenicol before $\mathrm{pH}$ shift from 7.2 to 5.0 followed by challenge at $\mathrm{pH}$ 3.5. The arrows indicate the times when the chloramphenicol and acid $\mathrm{pH}$ treatments were conducted for each culture.

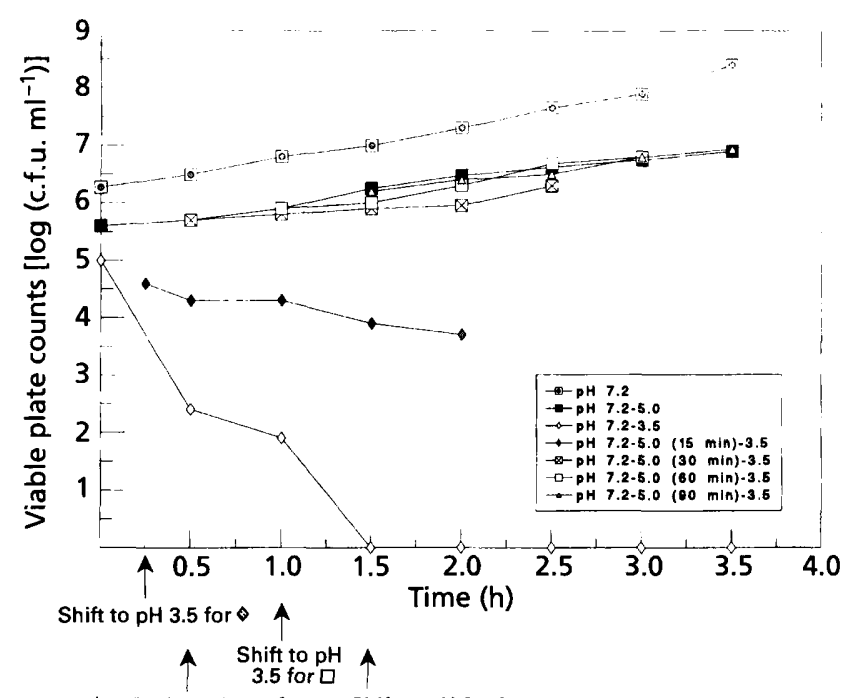

A Shift to $\mathrm{pH} 3.5$ for $₫$ Shift to $\mathrm{pH} 3.5$ for $\Delta$

Shift to $\mathrm{pH} 5.0$ for $\mathrm{O}$

Shift to $\mathrm{pH} 3.5$ for $\diamond$

Fig. 3. Viable plate counts of acid induction in cultures of $A$. hydrophila incubated at adaptation $\mathrm{pH}$ of 5.0 for $15,30,60$ or $90 \mathrm{~min}$ followed by shift to challenge $\mathrm{pH}$ of 3.5. Following the shift to $\mathrm{pH} 3 \cdot 5$, an aliquot of cells at every 30 min interval was serially diluted and plated on LB agar for viable plate counts. Cells grown at $\mathrm{pH} 7 \cdot 2, \mathrm{pH} 7 \cdot 2-5 \cdot 0$, and $\mathrm{pH} 7 \cdot 2-3.5$ were used as controls. Arrows indicate the times when the $\mathrm{pH}$ was shifted for each culture. The experiment was performed in triplicate. Comparable results were obtained in both LB and glucose minimal media.

throughout the experiment showed increased growth. The cultures in minimal salt medium and those in LB medium showed comparable results. 


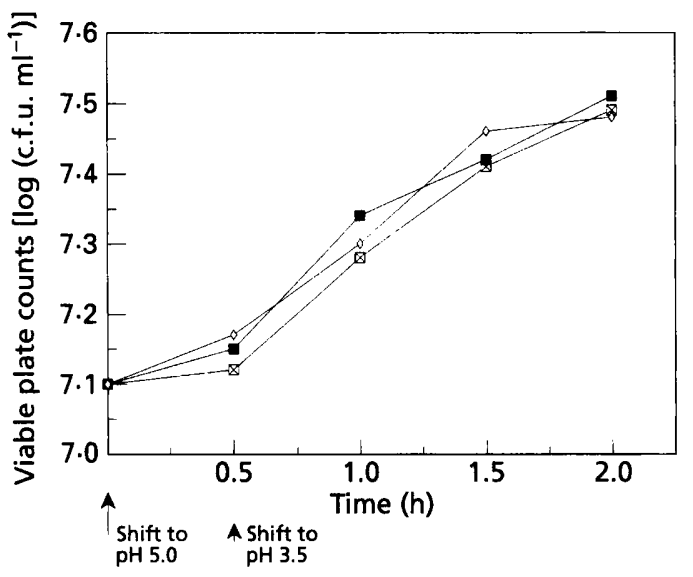

Fig. 4. Viable plate counts of acid induction in cultures of A. hydrophila incubated with dipyridyl (DTPA; $\otimes)$ or $\mathrm{DTPA}+\mathrm{Fe}(\mathrm{OH})_{3}(\mathrm{G})$. Following treatment, the cultures were adapted to $\mathrm{pH} 5.0$ for 20 min followed by a shift to challenge $\mathrm{pH}$ of 3.5. Before and after the shift to chalienge $\mathrm{pH}$, at every $30 \mathrm{~min}$ interval, aliquot of each culture was serially diluted and plated on LB agar for viable plate counts. Arrows indicate the shift in all cultures. Control culture was $\mathrm{pH} 7 \cdot 2-5 \cdot 0-3.5(\diamond)$. The experiment was performed in triplicate. Both LB and minimal salts media showed comparable results.

\section{Role of iron in acid adaptation}

The DTPA-treated culture showed survival at the challenge $\mathrm{pH}$ of 3.5 following adaptation at $\mathrm{pH} 5.0$ indicating that iron is not required for acid adaptation in $A$. bydrophila. The growth and survival of the DTPA culture was comparable with the culture treated with $\mathrm{DTPA}+\mathrm{Fe}(\mathrm{OH})_{3}$ and the culture adapted at $\mathrm{pH} 5.0$ followed by challenge to $\mathrm{pH} 3 \cdot 5$ (Fig. 4).

\section{Two-dimensional polyacrylamide gel analysis of ATR proteins}

Since acid tolerance required new protein synthesis for adaptation, an attempt was made to identify changes in polypeptides that occur in response to acidification. Since labelling of proteins for gel analysis requires growth in minimal media, it was first crucial to confirm that $A$. bydrophila could mount an ATR in glucose salts minimal medium. Cells were subjected to the acid induction procedure described in Methods using minimal glucose medium. The results were similar to those in rich medium (LB), suggesting that the ATR proteins were being produced in glucose salts minimal medium and therefore could be radiolabelled by incorporation of radiolabelled amino acids (data not shown).

The two-dimensional protein profiles of $A$. bydropbila at pH $5 \cdot 0$ and $\mathrm{pH} 7 \cdot 2$ are shown in Fig. 5. Cells shifted to $\mathrm{pH} 5 \cdot 0$ exhibited a protein profile with marked differences from that displayed by cells grown at $\mathrm{pH} 7 \cdot 2$. An increase in production of at least 28 proteins was observed (arrows) upon the acid shift while a decrease in synthesis of 10 proteins (circles) was evident. One or more of these

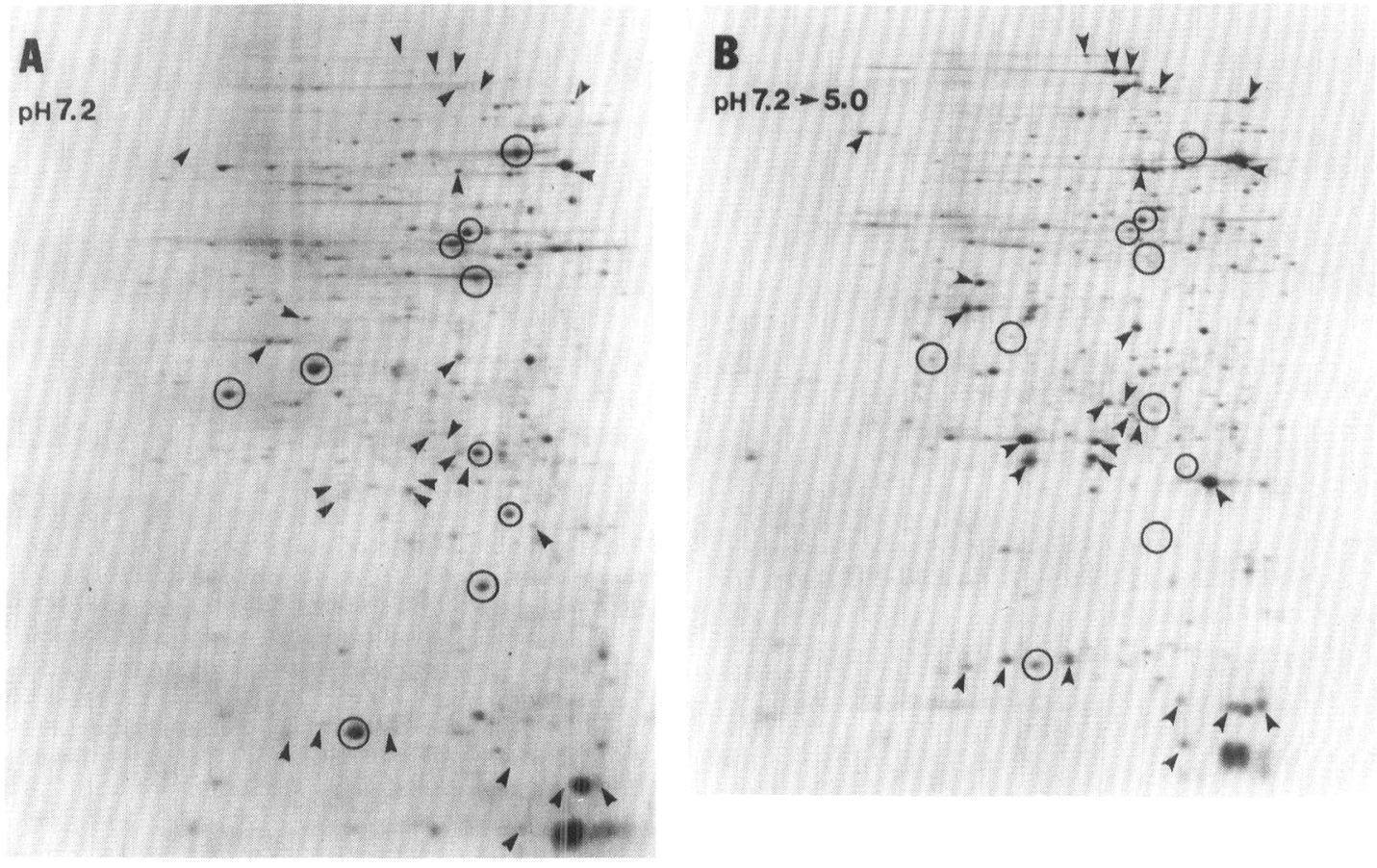

Fig. 5. Autoradiograms of two-dimensional PAGE analyses of the ATR proteins in A. hydrophila. A, Total cellular protein profile of a culture which was maintained at $\mathrm{pH} \mathrm{7.2;} \mathrm{B}$, total cellular protein profile of a culture in which the $\mathrm{pH}$ was shifted from pH 7.2 to 5.0 . The arrows indicate the increased synthesis of the proteins when the pH was shifted from 7.2 to 5.0 . The circles represent the decreased synthesis of proteins when the $\mathrm{pH}$ was shifted from $7 \cdot 2$ to 5.0 . 
proteins are likely to be responsible for survival at low acid $\mathrm{pH}$ since in their absence (when treated with chloramphenicol) cells are extremely acid sensitive. This protein response is similar to that seen in $S$. typhimurium (Foster, 1991) and in E. coli (Raja et al., 1991). Since this represents the first two-dimensional analysis of $A$. bydrophila polypeptides we do not know yet whether any of these protein changes may overlap those induced by other stress responses encountered by this organism.

ATR proteins induced by acid stress may protect cells by one or more possible mechanisms. First, newly synthesized proteins may bolster $\mathrm{pH}$ homeostasis enabling the cells to maintain internal $\mathrm{pH}$ close to neutral levels even at extremely low external $\mathrm{pH}$. Second, chaparonin proteins could be involved in protection of proteins from acid denaturation or damage. It is significant to note in this regard that the heat shock proteins GroEL and DnaK have been identified as being induced in S. typhimurium under acidic conditions (Foster, 1991; Buchmeier \& Heffron, 1990). Third, DNA binding proteins may play a role in habituation or adaptation to acid by preventing or repairing DNA damage as previously suggested in E. coli (Raja et al., 1991).

\section{CONCLUSIONS}

In the present study, we have shown that $A$. bydropbila can adapt to survive severe acid environments. This adaptation requires prior exposure to a relatively mild $\mathrm{pH}$ $(5 \cdot 0)$ before challenge at a much lower $\mathrm{pH}(3 \cdot 5)$. Also, acid adaptation in $A$. bydrophila requires new or increased synthesis of proteins since the addition of chloramphenicol prevents this phenomenon. A. bydrophila increases the synthesis of at least 28 proteins upon shifting cultures from $\mathrm{pH} 7 \cdot 2$ to $5 \cdot 0$, while simultaneously reducing the levels of 10 proteins. This suggests that the new proteins may have a significant role in protecting the cells in low $\mathrm{pH}$ conditions. The synthesis of additional proteins for adaptation to an acidic environment does not require iron. Also, the acid-adaptation proteins are not transient. The mild $\mathrm{pH}$ condition may act as a signal for the cell indicating potentially lethal $\mathrm{pH}$ changes in the external environment, allowing the cell to produce new 'protective' proteins required for survival at more acidic levels. This represents a global cellular response at both the physiological and genetic levels similar to those described in other bacterial species. Further studies on the genetic mechanism(s) whereby this bacterial pathogen can adapt and survive in harsh acid environments may provide insight into its ability to cause disease in humans.

\section{REFERENCES}

Aliabadi, Z., Park, Y. K., Slonczewski, J. L. \& Foster, J. W. (1988). Novel regulatory loci controlling oxygen- and $\mathrm{pH}$-regulated gene expression in Salmonella typhimurium. J Bacteriol 170, 842-851.

Allen, S. P., Polazzi, J. O., Gierse, J. K. \& Easton, A. M. (1992). Two novel heat shock genes encoding proteins produced in response to heterologous protein expression in Eschericbia coli. J Bacteriol 174, 6938- 6947.
Booth, I. R. (1985). Regulation of cytoplasmic $\mathrm{pH}$ in bacteria. Microbiol Rev 49, 359-387.

Buchmeier, N. A. \& Heffron, F. (1990). Induction of Salmonella stress proteins upon infection of macrophages. Science 248, 730-732.

Burke, V., Robinson, J., Gracey, M., Peterson, D. \& Partridge, K. (1984). Isolation of Aeromonas hydrophila from a metropolitan water supply: seasonal correlation with clinical isolates. Appl Environ Microbiol 48, 361-366.

Cumberbatch, N., Gurwith, M. J., Langston, C., Sack, R. B. \& Brunton, J. L. (1979). Cytotoxic enterotoxin produced by Aeromonas bydropbila: relationship of toxigenic isolates to diarrheal disease. Infect Immun 23, 829-837.

Dunn, B. E., Perez-Perez, G. I. \& Blaser, M. J. (1989). Twodimensional gel electrophoresis and immunoblotting of Campylobacter pylori proteins. Infect Immun 57, 1825-1833.

Figura, N., Marri, L., Verdiani, S., Ceccherini, C. \& Barberi, A. (1986). Prevalence, species differentiation, and toxigenicity of Aeromonas strains in cases of childhood gastroenteritis and in controls. J Clin Microbiol 23, 595-599.

Foster, J. W. (1991). Salmonella acid shock proteins are required for the acid tolerance response. J Bacteriol 173, 6896-6902.

Foster, J. W. (1992). Beyond $\mathrm{pH}$ homeostasis: the acid tolerance response of Salmonellae. Am Soc Microbiol 58, 266-267.

Foster, J. W. \& Hall, H. K. (1990). Adaptive acidification tolerance response of Salmonella typhimurium. J Bacteriol 172, 771-778.

Gluskin, I., Batash, D., Shoserov, D., Mor, A., Kazak, R., Azizi, E. \& Boldur, I. (1992). A 15-year study of the role of Aeromonas spp. in gastroenteritis in hospitalised children. J Med Microbiol 37, 315-318.

Goldstein, J., Pollitt, N. S. \& Inouye, M. (1990). Major cold shock protein of Eschericbia coli. Proc Natl Acad Sci US A 87, 282-287.

Goodson, M. \& Rowbury, R. J. (1989a). Resistance of acidhabituated Escherichia coli to organic acids and its medical and applied significance. Lett Appl Microbiol 8, 211-214.

Goodson, M. \& Rowbury, R. J. (1989b). Habituation to normally lethal acidity by prior growth of Escherichia coli at a sub-lethal acid $\mathrm{pH}$ value. Lett Appl Microbiol 8, 77-79.

Goodson, M. \& Rowbury, R. J. (1989c). Habituation to alkali in Escherichia coli. Lett Appl Microbiol 9, 71-73.

Goodson, M. \& Rowbury, R. J. (1990). Habituation to alkali and increased u.v. resistance in DNA repair-proficient and -deficient strains of Eschericbia coli grown at $\mathrm{pH} 9 \cdot 0$. Lett Appl Microbiol 11, 123-125.

Hamilton, I. R. \& Buckley, N. D. (1991). Adaptation by Streptococcus mutans to acid tolerance. Oral Microbiol Immunol 6, 65-71.

Hazen, T. C., Fliermans, C. B., Hirsch, R. P. \& Esch, G. W. (1978a). Prevalence and distribution of Aeromonas bydropbila in the United States. Appl Environ Microbiol 36, 731-738.

Hazen, T. C., Raker, M. L., Esch, G. W. \& Fliermans, C. B. (1978b). Ultrastructure of red-sore lesions on largemouth bass (Micropterus salmoides): association of the ciliate Epistylis sp. and the bacterium Aeromonas bydropbila. J Protozool 25, 351-355.

Henry, M. D., Yancey, S. D. \& Kushner, S. R. (1992). Role of the heat shock response in stability of mRNA in Escherichia coli $\mathrm{K}-12$. J Bacteriol 174, 743-748.

Hird, W., Diesch, S. L., McKinnel, R. G., Gorham, E., Martin, F. B., Kurtz, S. W. \& Dubrovolny, C. (1981). Aeromonas bydrophila in wildcaught frogs and tadpoles (Rana pipiens). Minn Lab Anim Sci 31, 166-169.

Janda, J. M. \& Duffey, P. S. (1988). Mesophilic aeromonads in human disease: current taxonomy, laboratory identification, and infectious disease spectrum. Rev Infect Dis 10, 980-997. 
Jenkins, D. E., Chaisson, S. A. \& Matin, A. (1990). Starvationinduced cross protection against osmotic challenge in Escherichia coli. J Bacteriol 172, 2779-2781.

Jenkins, D. E., Schultz, J. E. \& Matin, A. (1988). Starvation-induced cross protection against heat or $\mathrm{H}_{2} \mathrm{O}_{2}$ challenge in Escherichia coli. J Bacteriol 170, 3910-3914.

Jones, P., Krah, R., Tafuri, S. R. \& Wolffe, A. P. (1992). DNA gyrase, CS7.4, and the cold shock response in Escherichia coli. J Bacteriol 174, 5798-5802.

Kirov, S. M., Rees, B., Wellock, R. C., Goldsmid, J. M. \& Van Galen, A. D. (1986). Virulence characteristics of Aeromonas spp. in relation to source and biotype. J Clin Microbiol 24, 827-834.

Miller, J. H. (1972). Experiments in Molecular Genetics. Cold Spring Harbor, NY: Cold Spring Harbor Laboratory.

Monfort, P. \& Baleux, B. (1991). Haemolysin occurrence among Aeromonas bydropbila, Aeromonas caviae and Aeromonas sobria strains isolated from different aquatic ecosystems. Res Microbiol 142, 95-102.

Mooney, C., Munster, D. J., Bagshaw, P. F. \& Allardyce, R. A. (1990). Helicobacter pylori acid resistance. Lancet 335, 1232.

Murray, P. J. \& Young, R. A. (1992). Stress and immunological recognition in host-pathogen interactions. J Bacteriol 174, 4193 4196.

Nystrom, T. \& Neidhardt, F. C. (1992). Cloning, mapping and nucleotide sequencing of a gene encoding a universal stress protein in Escherichia coli. Mol Microbiol 6, 3187-3198.

Siegele, D. A. \& Kolter, R. (1992). Life after log. J Bacteriol 174, 345-348.

Pannekoek, Y., Putten, V., Jos, P. M. \& Dankert, J. (1992). Identification and molecular analysis of a 63-kilodalton stress protein from Neisseria gonnorboeae. J Bacteriol 174, 6928-6937.

Pitarangsi, C., Echeverria, P., Whitmire, R., Tirapat, C., Formal, S.,
Dammin, G. J. \& Tingtalapong, M. (1982). Enteropathogenicity of Aeromonas bydrophila and Plesiomonas shigelloides: prevalence among individuals with and without diarrhea in Thailand. Infect Immun 35, 666-673.

Raja, N., Goodson, M., Smith, D. G. \& Rowbury, R. J. (1991). Decreased DNA damage by acid and increased repair of aciddamaged DNA in acid-habituated Escherichia coli. J Appl Bacteriol 70, 507-511.

Schubert, R. H. W. (1991). Aeromonads and their significance as potential pathogens in water. J Appl Bacteriol Symp Suppl 70, 131S-135S.

Slonczewski, J. L. (1992). pH-regulated genes in enteric bacteria. Am Soc Microbiol 58, 140-144.

Spector, M. P., Aliabadi, Z., Gonzalez, T. \& Foster, J. W. (1986). Global control in Salmonella typbimurium: two-dimensional electrophoretic analysis of starvation-, anaerobiosis- and heat shockinducible proteins. J Bacteriol 168, 420-424.

Von Gravenitz, A. \& Mensch, A. H. (1968). The genus Aeromonas in human bacteriology. $N$ Engl J Med 278, 245-249.

Watson, N., Dunyak, D. S., Rosey, E. L., Slonczewski, J. L. \& Olson, E. R. (1992). Identification of elements involved in transcriptional regulation of the Escherichia coli cad operon by external $\mathrm{pH} . J$ Bacteriol 174, 530-540.

White, S., Tuttle, F. E., Blankenhorn, D. D., Donald, C. \& Slonczewski, J. L. (1992). $\mathrm{pH}$ dependence and gene structure of ina $A$ in Escherichia coli. J Bacteriol 174, 1537-1543.

Willimsky, G., Holger, B., Gunter, F. \& Mohamed, A. M. (1992). Characterization of $\operatorname{csp} B$, a Bacillus subtilis inducible cold shock gene affecting cell viability at low temperatures. $J$ Bacteriol 174, 63266335 .

Received 1 October 1993; revised 15 February 1994; accepted 21 February 1994. 